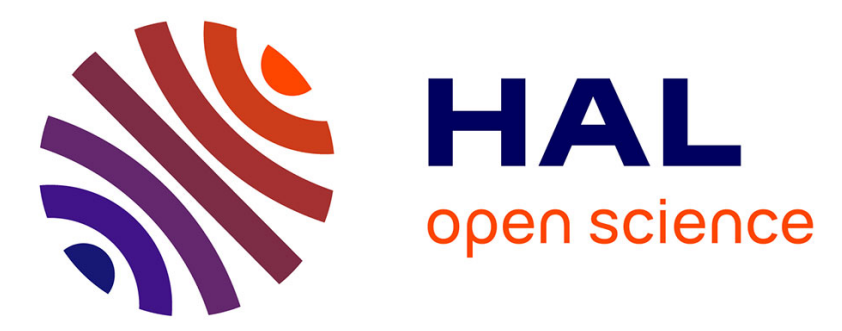

\title{
Evolution of the zonal gradients across the equatorial Pacific during the Miocene-Pleistocene
}

Catherine Beltran, Gabrielle Rousselle, Marc de Rafélis, Marie-Alexandrine Sicre, Nathalie Labourdette, Stefan Schouten

\section{- To cite this version:}

Catherine Beltran, Gabrielle Rousselle, Marc de Rafélis, Marie-Alexandrine Sicre, Nathalie Labourdette, et al.. Evolution of the zonal gradients across the equatorial Pacific during the MiocenePleistocene. Journal of Sedimentary Research, 2019, 89 (3), pp.242-252. 10.2110/jsr.2019.15 . insu02104911

\section{HAL Id: insu-02104911 https://hal-insu.archives-ouvertes.fr/insu-02104911}

Submitted on 13 Nov 2021

HAL is a multi-disciplinary open access archive for the deposit and dissemination of scientific research documents, whether they are published or not. The documents may come from teaching and research institutions in France or abroad, or from public or private research centers.
L'archive ouverte pluridisciplinaire $\mathbf{H A L}$, est destinée au dépôt et à la diffusion de documents scientifiques de niveau recherche, publiés ou non, émanant des établissements d'enseignement et de recherche français ou étrangers, des laboratoires publics ou privés. 
Title: Evolution of the zonal gradients across the Equatorial Pacific during the Miocene-

CATHERINE BELTRAN ${ }^{1,3}$, GABRIELLE ROUSSELLE ${ }^{1}$, MARC DE RAFÉLIS ${ }^{2}$, MARIE-

${ }^{1}$ Sorbonne Universités (UPMC, Université Paris 06), UMR 7193, ISTeP, Case Postale 116 - 4, place Jussieu 75005 Paris, France.

${ }^{2}$ Université Paul Sabatier, UMR 5563, Géosciences Environnements Toulouse - 14, avenue Edouard 11 Belin 31400 Toulouse, France.

${ }^{3}$ Department of Marine Science, University of Otago, PO Box 56, Dunedin 9054, New Zealand.

13 Present address. Corresponding author: catherine.beltran@otago.ac.nz

${ }^{4}$ Sorbonne Universités (UPMC, Université Paris 06)-CNRS-IRD-MNHN, LOCEAN Laboratory, 4 15 place Jussieu, F-75005 Paris, France.

$16{ }^{5}$ NIOZ Royal Netherlands Institute for Sea Research, Department of Marine Microbiology and 17 Biogeochemistry, and University of Utrecht, P.O. Box 59, 1790 AB Den Burg (Texel), The 18 Netherlands

19 'Departement of Earth Sciences, Utrecht University, Heidelberglaan 8, 3584 CS Utrecht, The 20 Netherlands

\section{ABSTRACT}

23 Combining $\mathrm{U}_{37}^{\mathrm{k}^{\prime}}$ - and $\mathrm{TEX}_{86}$-derived temperatures, and oxygen isotopic values of mixed24 layer and thermocline species from the IODP site U1338 (East Equatorial Pacific) and ODP 25 Site 806 (West Equatorial Pacific) we assess the evolution of the zonal sea-surface 26 temperature gradients and thermocline depth across the equatorial Pacific from the Late 
27 Miocene through the Pleistocene. Data suggest a long-term shoaling of the thermocline along the equator throughout the Miocene-Pliocene that accelerated around 5.3 Ma. We identify a critical transition at about 3.8 Ma from a El-Niño-like-dominated mean state during the Late Miocene and Early Pliocene to a La-Niña-like-dominated state during the Late Pliocene-

Pleistocene. This transition coincides with the restriction of the Indonesian seaway and the onset of ice growth in the northern hemisphere and in Antarctica that led to the long-term strengthening of the Walker circulation and affected low-latitude zonal gradient.

KEY WORDS: Equatorial Pacific, Miocene Pliocene climate, biomarker proxies, planktonic foraminifera, coccoliths.

\section{INTRODUCTION}

The equatorial Pacific Ocean plays an important role in the global climate by influencing the heat transport from low to mid- and high latitudes. The modern structure of the equatorial Pacific is characterized by a pronounced east-west asymmetry of the thermocline depth and of sea-surface temperature (SSTs) with the warm pool $\left(\sim 29^{\circ} \mathrm{C}\right)$ in the west and the cold tongue $\left(\sim 23^{\circ} \mathrm{C}\right)$ in the east (Fig. 1). The thermocline in the West Equatorial Pacific is deep and controls the flux of atmospheric latent heat (Tian et al., 2001) whereas in the east it is shallow and heat is absorbed (Boccaletti et al., 2004). The SSTs across the equatorial Pacific are affected by the El Niño-Southern Oscillation (Cane, 1998), one of the most important component of the global climate system, which alternates at inter-annual time scale between warm "El Niño" and cold "La Niña" phases.

The El Niño-Southern Oscillation is sensitive to the SST distribution across the equatorial 
al., 1998). Changes in the meridional SST gradient in the equatorial Pacific have important consequences on the local and global climate.

The modern setting of the equatorial Pacific was established during the mid- to late Miocene (LaRivière et al., 2012) through the progressive closure of the Central American Seaway (CAS) and the Indonesian Seaway (Keigwin, 1982; Haug and Tiedemann, 1998; Srinivasan and Sinha, 1998; Schneider and Schmittner, 2006) together with Northern Hemisphere Glaciation (Mudelsee and Raymo, 2005) (Fig. 2). During this period, the onset of the modern thermohaline circulation and equatorial upwelling led to the progressive cooling of deep water (Woodruff and Savin, 1989; Ravelo et al., 2004), upper-ocean stratification, and thermocline rise. Nathan and Leckie (2009) dated the proto warm pool in the West Equatorial Pacific (WEP) between 11.6 and 10 Ma. The thermocline depth asymmetry set up around 4.8 Ma and induced a well-documented cold-water tongue in the Eastern Equatorial Pacific (EEP) between 4.4 and 3.6 Ma (Chaisson and Ravelo, 2000; Wara et al., 2005; Steph et al., 2010; Rousselle et al., 2013).

Although numerous studies (e.g., Raymo et al., 1996; Haywood and Valdes, 2004; Ravelo et al., 2004, 2006; Rickaby and Halloran, 2005; Wara et al. 2005; Barreiro et al., 2005; Fedorov et al. 2006, 2013; Dekens et al. 2008; Brierley et al., 2009) established that the equatorial Pacific zonal gradients were weaker during the early Pliocene warm period (El Niño-like, El Padre) and stronger during the mid-Holocene (La Niña-like; Koutavas et al. 2006), there is no consensus on the long-term evolution of the equatorial Pacific mean state since the Miocene (Fig. 2). This is a major limitation to predict El Niño-Southern Oscillation, in that its behavior is closely related to long-term changes in tropical Pacific oceanography that are still not fully understood. Some authors suggest that the equatorial thermal state remained unchanged over the last 12 Myr (Zhang et al., 2014) whereas others identified alternating El Niño-like and La Niña-like conditions (Wara et al., 2005; Ravelo et al., 2006; Nathan and 
Leckie, 2009; Kamikuri et al., 2009; Drury et al., 2018) or a progressive shoaling of the thermocline over the last 13 Myr (LaRiviere et al., 2012).

Because the past variability of the equatorial Pacific mean state is also considered to have played a role in major climatic transitions (Yin and Battisti, 2001), reconstructing the longterm evolution of the thermal structure in this region is crucial.

While most published studies focus on very specific time intervals (e.g., Medina-Elizalde and Lea, 2010; Ford et al., 2015), the purpose of this study is to examine the long-term evolution of equatorial Pacific surface conditions over the last $10 \mathrm{Myr}$. To do so, surface and subsurface temperature records from IODP Site U1338 (EEP) (Fig. 1) are generated from both alkenones $\left(\mathrm{U}_{37}^{\mathrm{k}^{\prime}}\right)$ produced by coccolithophores (marine unicellular haptophyte algae, Brassell et al., 1986) and glycero- dialkyl glycerol- tetraethers (GDGTs, TEX ${ }_{86}$ ) produced by Thaumarchaeota (Archaea, Schouten et al., 2002; Kim et al., 2010). Additional hydrological information is provided by the oxygen-isotope composition of calcareous nannofossils Noelaerhabdaceae spp. calcifying in the photic zone and the thermocline-dweller foraminifera Globorotalia menardii (Martin, 1999; Spero et al., 2003) recovered from the ODP Site 806 (WEP) and IODP Site U1338 (Fig. 1).

\section{OCEANOGRAPHIC SETTING}

The equatorial Pacific surface ocean circulation, controlled by the Walker cell and Trade winds, results in two westward surface currents, the North and South Equatorial Currents, respectively (SEC and NEC; Fig. 1). The easterly winds pile warm waters in the WEP and create a subsurface eastward circulation known as the Equatorial Under Current (EUC), which brings cold and nutrient-rich waters to the surface in the EEP. The subsequent thinning of the mixed-layer and formation of a cold tongue in the EEP produce a strong W-E asymmetry of the equatorial thermocline depth, deeper in the West Pacific than in the East Pacific (Fig. 1). The modern equatorial SST gradient across the Pacific varies in response to 
101 the inter-annual El Nino-Southern Oscillation. During El Niño years, the trade winds weaken, 102 the thermocline deepens in the EEP, and the equatorial upwelling attenuates. As a 103 consequence, the equatorial SST gradient is reduced, mean temperatures are warmer, and the 104 extratropical heat distribution is impacted (Molnar and Cane, 2002; McPhaden et al., 2006).

105 Since the Miocene, the Pacific zonal temperature gradients and the thermocline tilt have

106 varied. Extended periods of reduced equatorial SST gradient and deep thermocline that mimic 107 the modern El Niño events are called permanent El Niño-like states. Similarly, periods of 108 long-term strong equatorial Pacific zonal gradients are called La Niña-like states.

\section{MATERIALS AND METHODS}

\section{IODP Site U1338 and ODP Site 806}

111 The IODP Site U1338 ( $2^{\circ} 30.469^{\prime} \mathrm{N}, 117^{\circ} 58.178^{\prime} \mathrm{W}, 4200$ meters water depth, leg 321$)$ was

112 drilled in the EEP, in the modern cold tongue (Pälike et al., 2010) (Fig. 1). Despite the 113 northward drift of the Pacific plate, this site remained in the equatorial band for the past 10

114 Myr (Pälike et al., 2010). Sediments at Site U1338 were deposited above the calcite 115 compensation depth (Pälike et al., 2012) and are composed of well-preserved biogenic 116 material, predominantly nannofossil oozes, with variable abundances of diatoms, radiolarians, 117 and foraminifera (Pälike et al., 2010). The age model of the core was constructed from 118 biostratigraphic (nannofossils, foraminifers, diatoms, and radiolarians) and paleomagnetic 119 data (Pälike et al., 2010; Backman et al., 2016). Average sedimentation rates are relatively 120 high for the studied time interval ( $27 \mathrm{~m} / \mathrm{Myr})$.

121 ODP Site $806\left(0^{\circ} 19,1^{\prime} \mathrm{N}, 159^{\circ} 21,7^{\prime} \mathrm{E}, 2520\right.$ meters water depth, leg 130) is located on the 122 northeast margin of the Ontong Java plateau in the area of the WEP warm pool (Fig. 1).

123 Sediments are composed mostly of well-preserved calcareous nannofossils and planktic 124 foraminifera. The age model is based exclusively on biostratigraphic data of calcareous 125 nannofossils, foraminifera, diatoms, and radiolarians established by Kroenke et al. (1991), 
126 later refined by Takayama (1993) and Chaisson and Leckie (1993). Ages are corrected based

127 on biostratigraphic data of Backman et al. (2016) (see Supplement). The average

128 sedimentation rate at this site is higher than at U1338, ranging from $\sim 45 \mathrm{~m} / \mathrm{Myr}$ between 9

129 and $5 \mathrm{Ma}$ to $\sim 29 \mathrm{~m} / \mathrm{Myr}$ during the Pliocene.

130 Proxy records at both sites are generated for the period between 10 and $0.18 \mathrm{Ma}$ using 131 samples from sections U1338B-22H7W through U1338B-1H2W and sections 806B-37X3W 132 through 806B-1H1W. The average sampling resolution of these records varies between 100 133 kyr and $400 \mathrm{kyr}$.

135 To determine changes in the thermocline depth in the EEP and WEP through time, we 136 measured the oxygen-isotope ratios $\left(\delta^{18} \mathrm{O}\right)$ in the calcite of calcareous-nannofossil-enriched 137 fractions and of the upper-thermocline-dweller planktonic foraminifera Globorotalia 138 menardii. Calcareous nannofossils calcify mainly in the photic zone and thus are used to 139 derive surface-water properties (Roth, 1986) whereas G. menardii is selected to assess 140 subsurface water changes.

$141 \delta^{18} \mathrm{O}$ values are measured on calcareous nannofossils Noelaerhabdaceae spp. isolated from

142 the bulk sediment following the procedure of Minoletti et al. (2009). $\delta^{18} \mathrm{O}$ measurements are 143 performed on the $2-5 \mu \mathrm{m}$ fractions at both sites. For site U1338, we use the $\delta^{18} \mathrm{O}$ data previously 144 published by Rousselle et al. (2013) based on the same protocol as in the present study. $145 \delta^{18}$ Ovalues are measured using a Finnigan Delta $\mathrm{E}$ mass spectrometer at $50^{\circ} \mathrm{C}$, at a temporal 146 resolution of $400 \mathrm{kyr}$. The quality of the granulometric separation based on 200 particles 147 counting in smear slides is estimated to be at least $75 \%$ except between 8 and 9 Ma at Site 148 806, where Sphenolitus abies dominated. These measurements are thus not considered here.

149 In addition, five to seven specimens of G. menardii were hand-picked from the $>160 \mu \mathrm{m}$ 150 fractions for isotopic measurements. Analyses are performed on a VG ISOPRIME at $90^{\circ} \mathrm{C}$ 
with a precision of $0.1 \%$ and expressed with reference to the VPDB international standard. 45 samples at Site U1338 and 99 samples at Site 806 were analyzed. The average temporal resolution over the last $10 \mathrm{Myr}$ is comprised between 120 and $150 \mathrm{ka}$.

Alkenone-derived SSTs of Site U1338 previously reported by Rousselle et al., (2013) are supplemented in the present study with 23 additional samples selected from the Pliocene interval (U1338B-8H5W to U1338B-1H2W) to reach a temporal resolution of $100 \mathrm{kyr}$. Sedimentary alkenones are analyzed following the procedure described by Ternois et al. (2000). About $5 \mathrm{~g}$ of freeze-dried sediments are extracted in a mixture of $\mathrm{CH}_{2} \mathrm{Cl}_{2} / \mathrm{CH}_{3} \mathrm{OH}$.

160 Alkenones are isolated from the total lipid extract by silica-gel chromatography using 161 solvents of increasing polarity. The fraction containing alkenones is concentrated, transferred into clean glass vials, and evaporated under a nitrogen stream. Gas-chromatography analyses are performed using a Varian $3400 \mathrm{CX}$ series equipped with a septum programmable injector

164 (SPI) and a flame ionization detector (FID). We use a fused silica capillary column 165 (Chrompack CP Sil5CB, $50 \mathrm{~m}$ long, $0.32 \mathrm{~mm}$ internal diameter, $0.25 \mu \mathrm{m}$ film thickness) and 166 helium as a carrier gas. The alkenone unsaturation ratio $\mathrm{U}^{\mathrm{K}}{ }_{37}\left(\mathrm{C}_{37: 2} /\left(\mathrm{C}_{37: 2}+\mathrm{C}_{37: 3}\right)\right.$ is converted 167 into SSTs using the Conte et al. (2006) calibration: $\mathrm{T}=-0.957+54.293\left(\mathrm{U}^{\mathrm{K}}{ }^{3}{ }\right)-52.894$ $168\left(\mathrm{U}^{\mathrm{K}^{\prime}}{ }_{37}\right)^{2}+28.321\left(\mathrm{U}^{\mathrm{K}}{ }_{37}\right)^{3}$, which provides more accurate estimates in warm-temperature 169 range than Prahl et al. (1988). Average external precision of the SSTs using this calibration 170 has been estimated at $\sim 1.2^{\circ} \mathrm{C}$ (Conte et al., 2006). Replicate analyses indicate internal 171 precision of $\pm 0.5^{\circ} \mathrm{C}$. Because of the limited amount of sediment material at Site 806 (where 172 alkenone concentrations are extremely low), previously published data from Pagani et al. 173 (2010) provide data covering the past $5 \mathrm{Myr}$. Note that we recalculated SSTs from the $\mathrm{U}^{\mathrm{K}}{ }_{37}$ 174 values of Pagani et al. (2010) using the Conte et al. (2006) calibration to avoid calibration 175 bias between sites (see Supplement). 
177 Forty samples from Site U1338 were analyzed for GDGTs at the Netherlands Institute for Sea

178 Research (NIOZ, Texel, The Netherlands). About $5 \mathrm{~g}$ of sediment are freeze dried and

179 extracted in a mixture of $\mathrm{CH}_{2} \mathrm{Cl}_{2}$ and $\mathrm{CH}_{3} \mathrm{OH}$. The total lipid extracts are separated following

180 the protocol described in Schouten et al. (2002), using $\mathrm{Al}_{2} \mathrm{O}_{3}$ column chromatography to

181 separate non-polar compounds from the polar GDGTs. Polar fractions are then filtered

182 through a $0.4 \mu \mathrm{m}$ pore-size filter, evaporated under nitrogen, and diluted to a concentration of

$1832 \mathrm{mg} / \mathrm{ml}$. GDGTs are analyzed using an Agilent HP1100 (HPLC) equipped with a Prevail

184 Cyano column $(3 \mu \mathrm{m}, 150 \mathrm{~mm}$ x $2.1 \mathrm{~mm})$ following Schouten et al. (2007). The TEX 86 index

185 is calculated using peak areas of the following GDGTs as defined by Schouten et al. (2002):

186 TEX $_{86}=[$ GDGT2] $+[$ GDGT3] $+[$ GDGT5'] $/[$ GDGT1 $]+[$ GDGT2] $+[$ GDGT3] $+[$ GDGT5']. The

$187 \mathrm{TEX}^{\mathrm{H}} 86$, defined as the $\log \left(\mathrm{TEX}_{86}\right)$, is used to calculate temperatures over the past 9 Myr.

188 Temperatures are calculated using the calibration established for temperatures above $15^{\circ} \mathrm{C}$ by

189 Kim et al. (2010) $\left(\mathrm{T}=68.4 * \mathrm{TEX}_{86}^{\mathrm{H}}+38.6\right)$. The error on temperature estimates is $\pm 2.5^{\circ} \mathrm{C}$.

190 Other calibrations have been proposed for $\mathrm{TEX}_{86}$ temperatures, in particular based on

191 Bayesian statistics (Tierney and Tingley, 2015) but these yield results similar to those shown

192 here, whereas the Kim et al. (2010) calibration is consistent with other studies from this area

193 (e.g., Seki et al., 2010; Zhang et al., 2014). $\mathrm{TEX}^{\mathrm{H}}{ }_{86}$ - derived temperatures are obtained at a

194 mean temporal resolution of $230 \mathrm{kyr}$. At Site 806, because of the very low GDGT

195 concentrations, we use previously published data from Zhang et al. (2014) covering the past

19612 Myr for comparison with the data from Site U1338.

\section{RESULTS}


200 The oxygen stable-isotope signatures of the Noelaerhabdaceae-enriched fine fractions $201\left(\delta^{18} \mathrm{O}_{\text {Noelaerhabdaceae }}\right)$ vary between $-1.5 \%$ and $0.5 \%$ (Fig. 3A). $\delta^{18} \mathrm{O}_{\text {Noelaerhabdaceae }}$ progressively 202 increase between $8 \mathrm{Ma}$ and $5 \mathrm{Ma}$, before declining to -1.3\%o until 2.7 Ma and rising again to $2030.4 \%$. The $\delta^{18} \mathrm{O}_{\text {Noelaerhabdaceae }}$ record is similar to the higher resolution $\delta^{18} \mathrm{O}$ record of the 204 surface dweller G. sacculifer from the nearby Site 847 covering only the last 5 Myr (Wara et 205 al., 2005) (Figs. 1, 3A).

$206 \delta^{18} \mathrm{O}$ values measured on the thermocline-dwelling planktonic foraminifera $G$. menardii $207\left(\delta^{18} \mathrm{O}_{\text {G.menardii }}\right)$ over the last $8 \mathrm{Myr}$ (Figure 3A) demonstrate that values vary between $-1.4 \%$ 208 and $1.25 \%$ and display trends similar to those of $\delta^{18} \mathrm{O}_{\text {Noelaerhabdaceae }}$ until 5 Ma. Then, $209 \delta^{18} \mathrm{O}_{\text {G.menardii }}$ become more positive than $\delta^{18} \mathrm{O}_{\text {Noelaerhabdaceae }}$ and still increase until $0.4 \mathrm{Ma}$, as 210 also recorded in the deep thermocline dweller $G$. tumida $\delta^{18} \mathrm{O}$ values $\left(\delta^{18} \mathrm{O}_{\text {G.tumida }}\right)$ at Site 847 211 (Figs. 1, 3A; Wara et al., 2005).

$213 \delta^{18} \mathrm{O}_{\text {Noelaerhabdaceae }}$ at site 806 vary within a range similar (between -2.8 and $0.9 \%$ ) to site $214 \mathrm{U} 1338$ (Fig. 3B). $\delta^{18} \mathrm{O}_{\text {Noelaerhabdaceae }}$ values are relatively stable (around $0 \%$ ) between $7 \mathrm{Ma}$ 215 and 4.4 Ma and rapidly decline to more negative values between 4.5 Ma and $4 \mathrm{Ma}$, after 216 which values remain stable until $0.38 \mathrm{Ma}$. The $\delta^{18} \mathrm{O}_{\text {G.menardii }}$ record at Site 806 shows a long217 term decrease between 9.7 Ma and 7 Ma and becomes stable until 1.9 Ma. At 3.7 Ma oxygen218 isotope values decrease sharply by $1 \%$, and again between $2.5 \mathrm{Ma}$ and $1.8 \mathrm{Ma}$. The $219 \delta^{18} \mathrm{O}_{\text {G.menardii }}$ values then increase to higher values $(-0.4 \%)$ until $0.5 \mathrm{Ma}$ and further to $0.5 \%$ at 0.2 Ma. Overall, $\delta^{18} \mathrm{O}_{\text {Noelaerhabdaceae }}$ and $\delta^{18} \mathrm{O}_{\text {G.menardii }}$ reveal more positive values in the EEP

221 than in the WEP and include larger-amplitude variations. EEP Temperature Reconstructions.

223 Alkenone-derived SSTs $\left(\mathrm{SST}_{\mathrm{U}}{ }^{\mathrm{K}}{ }^{3}\right)$ at Site U1338 are relatively stable and warm $\left(\sim 27^{\circ} \mathrm{C}\right)$ between $10 \mathrm{Ma}$ and $6.8 \mathrm{Ma}$ (Fig. 4A). They cool by $1^{\circ} \mathrm{C}$ between $6.8 \mathrm{Ma}$ and $5.6 \mathrm{Ma}$, and 
show a broad warming until 3.7 Ma. From 3.7 Ma onwards, SSTs depict another cooling of about $4^{\circ} \mathrm{C}$ and superimposed cold episodes of 1 to $2^{\circ} \mathrm{C}$ amplitude around 2.9 Ma, 1.7 Ma, and $0.5 \mathrm{Ma}$.

From the Late Miocene to the Pleistocene, $\mathrm{TEX}_{86}$-derived temperatures $\left(\mathrm{T}_{\mathrm{TEX}}\right)$ indicate a long-term cooling. Between 8 and $5 \mathrm{Ma}, \mathrm{T}_{\mathrm{TEX}}$ and the $\mathrm{SST}_{\mathrm{U}}{ }^{\mathrm{K}}{ }_{37}$ vary in the same range of 230 values (between $24^{\circ} \mathrm{C}$ and $27^{\circ} \mathrm{C}$; Fig. 4A), although they are slightly cooler. From approx. 4.5 231 Ma, the two temperature proxies show marked temperature difference. Note that $\mathrm{T}_{\mathrm{TEX}}$ 232 increase around 7.5 Ma and 4.8 Ma, reaching values close to $\operatorname{SST}_{\mathrm{U}}{ }^{\mathrm{K}}{ }_{37}$.

$233 \mathrm{SST}_{\mathrm{U}}{ }^{\prime}{ }_{37}$ at Site $\mathrm{U} 1338$ are warmer than $\mathrm{T}_{\mathrm{TEX}}$ by 2 to $3^{\circ} \mathrm{C}$ on average. Both progressively cool 234 down between $9 \mathrm{Ma}$ and $0.18 \mathrm{Ma}$ but $\mathrm{T}_{\mathrm{TEX}}$ decreases by $5^{\circ} \mathrm{C}$ while $\mathrm{SST}_{\mathrm{U}}{ }^{\prime}{ }_{37}$ cools by only $235 \quad 3^{\circ} \mathrm{C}$ (Fig. 4A).

\section{DISCUSSION}

Warmer $\mathrm{SST}_{\mathrm{U}} \mathrm{K}^{\prime}{ }_{37}$ than $\mathrm{T}_{\mathrm{TEX}}$, as observed at Site U1338, is reported in several studies (e.g.,

Huguet et al., 2007; Lee et al., 2008; Leider et al., 2010; Lopes dos Santos et al., 2010;

240 Rommerskirchen et al., 2011; Seki et al., 2012; Zhang et al., 2014) and explained by different 241 depth habitat or season of production. However, because seasonality is weak at low latitudes, 242 it is unlikely to explain a temperature differences of up to $4^{\circ} \mathrm{C}$, at Site U1338. Unlike 243 haptophytes thriving in the photic zone, Thaumarchaeota, the sources of the GDGTs, occur 244 throughout the water column (e.g., Karner et al., 2001; Huguet et al., 2007), and the export of 245 GDGTs can be integrated for a larger part of the upper part of the ocean, likely including a 246 part of the thermocline. Wuchter et al. (2005) reported maximum concentrations of GDGTs 247 between 100 and $200 \mathrm{~m}$ depth in the Pacific Ocean, coinciding with high ammonium 248 concentrations below the photic zone (Murray et al., 1999; Karner et al., 2001; Wuchter et al., 249 2005; Huguet et al., 2007; Pearson et al., 2007). GDGT producers can thus preferentially 
develop in subsurface or deeper waters (Huguet et al., 2007; Kim et al., 2008; Lee et al., 2008; Huguet et al., 2011; Kim et al., 2012). The difference between $\mathrm{T}_{\mathrm{TEX}}$ and $\mathrm{SST}_{\mathrm{U}}{ }^{\mathrm{K}}{ }_{37}$ in the EEP may then account for different production or export depth (Lopes dos Santos et al., 2010;

Rommerskirchen et al., 2011; Schouten et al., 2013).

254 The interpretation of $\mathrm{T}_{\text {твх }}$ temperatures across the equatorial Pacific is complicated by both the 255 upwelling in the EEP and the different trophic conditions between the EEP and the WEP that influence the export depth of GDGTs (Seki et al., 2012). Numerous studies indicate that upwelling impacts on the depth of production and export of GDGTs to the sediment (Wuchter et al., 2005; Huguet et al., 2007; Lee et al., 2008; Lopes dos Santos et al., 2010; Seki et al., 2012). In the absence of upwelling, $\mathrm{T}_{\mathrm{TEX}}$ reflects the surface temperatures (Sinninghe Damsté et al., 2002; Wakeham et al., 2004) whereas under upwelling conditions, $\mathrm{T}_{\mathrm{TEX}}$ represent thermocline temperatures (Wakeham et al., 2002; Wuchter et al., 2005; Huguet et al., 2007).

262 Furthermore, the nitrate maximum across the modern equatorial Pacific exhibits a clear asymmetry in the depth. Könneke et al. (2005) found that the production of Thaumarchaeota

264 occurs in the subsurface nitrate maximum, which thus is deeper in oligotrophic regions such 265 as the WEP (Brzezinski, 1988). As a consequence, within the same basin $\mathrm{T}_{\text {TEX }}$ may reflect 266 surface and subsurface conditions in response to different environmental factors (Hertzberg et 267 al., 2016).

268 In the EEP, the $\mathrm{T}_{\mathrm{TEX}}-\mathrm{SST}_{\mathrm{U}}{ }^{\mathrm{K}}{ }_{37}$ temperature gradient $(\Delta \mathrm{T})$ is proposed to monitor changes of 269 the thermocline depth (Seki et al., 2012) assuming that $\Delta \mathrm{T}$ is driven by the depth migration of 270 GDGT producers in response to upwelling activity. Therefore, at Site U1338, warming TTEX 271 and reduced $\Delta \mathrm{T}$ reflect a deep thermocline and surface export of GDGTs, whereas a more 272 pronounced cooling of $\mathrm{T}_{\mathrm{TEX}}$ compared to $\mathrm{SST}_{\mathrm{U}}{ }^{\mathrm{K}}{ }_{37}$, (increased $\Delta \mathrm{T}$ ) reflects a shallow 273 thermocline, upwelling activity, and subsurface export of GDGTs. 
274 In the WEP, the interpretation of $\mathrm{T}_{\mathrm{TEX}}-\mathrm{SST}_{\mathrm{U}}{ }^{\mathrm{K}}{ }_{37}$ is not straightforward either. At Site 806, $275 \mathrm{SST}_{\mathrm{U}}{ }^{\prime}{ }_{37}$ calculated from Pagani et al., (2010) are warm and stable, averaging 28 to $28.5^{\circ} \mathrm{C}$ 276 over the last $5 \mathrm{Myr}$ (Fig. 4C) except for a $2^{\circ} \mathrm{C}$ sharp cooling at $\sim 1.5 \mathrm{Ma}$. High-resolution $277 \mathrm{Mg} / \mathrm{Ca}$-derived SSTs $\left(\mathrm{SST}_{\mathrm{Mg} / \mathrm{Ca}}\right.$ ) corrected from $\mathrm{Mg} / \mathrm{Ca}_{\text {seawater }}$ (Medina-Elizalde et al., 2008) 278 from the same site show markedly warmer conditions in the surface of the WEP especially 279 between 5 and $3.5 \mathrm{Ma}$, reaching up to $32^{\circ} \mathrm{C}$. This difference with the alkenone-derived 280 temperatures can be attributed to (1) the alkenone calibration being less accurate in the 281 warmer temperature range (Conte et al., 2006), thus leading to the underestimation of $282 \mathrm{SST}_{\mathrm{U}}{ }^{\prime}{ }_{37}$ (Tierney and Tingley 2018) or (2) the uncertainties on the seawater $\mathrm{Mg} / \mathrm{Ca}$ 283 correction. However, from 3 Ma onwards, $\mathrm{SST}_{\mathrm{U}}{ }^{\prime}{ }_{37}$ and $\mathrm{SST}_{\mathrm{Mg} / \mathrm{Ca}}$ temperatures display 284 similar trends and values, except between 1.8 Ma and 1.2 Ma, when they diverge. Since this 285 discrepancy coincides with isotopic changes (Fig. 3) we can reasonably conclude that the 286 difference between the two records during the late Pliocene reflects oceanographic changes.

287 During the early Pliocene, cooler $\mathrm{SST}_{\mathrm{U}}{ }^{\mathrm{K}}{ }_{37}$ appear to be linked to a calibration limitation of 288 the proxy at warm temperatures.

289 Comparison between the $\mathrm{T}_{\mathrm{TEX}}$ record (Zhang et al., 2014) and subsurface temperatures 290 derived from $\mathrm{Mg} / \mathrm{Ca}_{\text {G.tumida }}$ (Ford et al., 2015) at ODP Site 806, highlights that from 5 to 3.5 291 Ma both reconstructions agree well within their uncertainties (Fig. 4C). From 3.5 to 2 Ma, $292 \mathrm{~T}_{\mathrm{TEX}}$ match with $\mathrm{SST}_{\mathrm{U}} \mathrm{K}^{\prime}{ }_{37}$ and $\mathrm{Mg} / \mathrm{Ca}$-derived SSTs from the surface dweller G. ruber 293 ( $\mathrm{Mg} / \mathrm{Ca}_{\text {G.ruber }}$ Medina-Elizalde et al., 2008), whereas $\mathrm{Mg} / \mathrm{Ca} a_{\text {G.tumida }}$ temperatures are 294 systematically cooler than $\mathrm{T}_{\mathrm{TEX}}$ (Fig. 4C). After 1.3 Ma, $\mathrm{T}_{\mathrm{TEX}}$ values are intermediate between $295 \mathrm{Mg} / \mathrm{Ca}_{\text {G.ruber }}$ and $\mathrm{Mg} / \mathrm{Ca} a_{\text {.tumida }}$ temperatures, while $\mathrm{SST}_{\mathrm{U}^{\mathrm{K}}}{ }_{37}$ tend to agree with $\mathrm{Mg} / \mathrm{Ca}$ G.ruber 296 SSTs. It is likely that in the WEP, the $\mathrm{T}_{\mathrm{TEX}}$ reflect production in different water depth in 297 response to trophic changes and environmental conditions. We speculate that during the warm 298 early Pliocene and after 1.3 Ma, $\mathrm{T}_{\text {TEX }}$ reflect subsurface conditions and that during the Late 
Pliocene, the export of GDGTs derived mainly from surface waters. This interpretation

300

301

302

\section{3}

304

305

306

307

308

309 nuances the interpretations of Zhang et al. (2014), who considered that $\mathrm{T}_{\mathrm{TEX}}$ reflect surface temperatures and could be used as an alternative to $\mathrm{U}^{\mathrm{K}}{ }^{\prime}{ }_{37}$ under warm conditions.

\section{Changes in the Equatorial Pacific Mean State over the Last 10 Myr}

To investigate the evolution of the surface stratification across the Equatorial Pacific, we calculate the oxygen-isotope gradients between Noelaerhabdaceae and G. menardii $\left(\Delta \delta^{18} \mathrm{O}\right)$ (Fig. 4B) (Nathan and Leckie, 2009; Beltran et al., 2014). Note that in doing so, the sea-water $\delta^{18} \mathrm{O}$ component is factored out. Higher (lower) $\Delta \delta^{18} \mathrm{O}$ values reflect a shallower (deeper) thermocline (Ravelo and Fairbanks, 1992; Ravelo and Shackleton, 1995; Farell et al., 1995; Nathan and Leckie, 2009, Beltran et al., 2014).

Variations in the gradient between $\mathrm{T}_{\mathrm{TEX}}$ and $\mathrm{SST}_{\mathrm{U}}{ }^{\mathrm{K}}{ }_{37}$ also can be used to evaluate changes in the thermocline depth. $\mathrm{T}_{\mathrm{TEX}}$ and $\mathrm{SST}_{\mathrm{U}}{ }^{\prime}{ }_{37}$ values similar to those observed between $7.3 \mathrm{Ma}$ and 6.8 Ma, and around 4.8 Ma at IODP Site U1338, indicate a deep thermocline (Fig. 4A).

Some intervals are characterized by an increase in $\Delta \mathrm{T}$ (such as, for example, between $6.8 \mathrm{Ma}$ and 5.3 Ma at IODP Site U1338) associated with a cooling trend of both proxies. These features indicate that GDGTs are produced deeper and that surface waters are concomitantly cooling, which is consistent with upwelling activity.

Based on temperatures and isotopic gradients between surface and subsurface waters from the EEP and WEP, the data reveal a pronounced oceanographic change at $c a .5 \mathrm{Ma}$ with the thermocline progressively rising (Fig. 4A, 4B).

\section{Late Miocene [9 - 5.3 Ma] Interval.---}

During the late Miocene period, east and west $\Delta \delta^{18} \mathrm{O}$ are reduced and stable, indicating a deep thermocline across the equatorial Pacific (Fig. 4B). From 10 Ma to $6.3 \mathrm{Ma}$, data indicate warm SSTs $\left(\sim 27^{\circ} \mathrm{C}\right)$ in the EEP (Fig. 4A). This result coincides with the low abundances of upwelling radiolarian species reported between 9 and 7 Ma by Kamikuri et al. (2009). Similar 
$324 \operatorname{SST}_{\mathrm{U}}{ }^{\mathrm{K}}{ }_{37}$ and $\mathrm{T}_{\mathrm{TEX}}$ values at U1338 between 7.3 and $6.8 \mathrm{Ma}$ also is consistent with a thick 325 mixed layer in the EEP (Fig. 4A; Seki et al., 2012). In the WEP, Nathan and Leckie (2009)

326 reported a similar decrease in the abundance of surface dwellers in favor of thermocline 327 species, which suggests a deep thermocline. This reduced zonal gradient in SSTs and 328 thermocline tilt across the equatorial Pacific corresponds to El Niño-like conditions, in 329 agreement with earlier findings of Herbert et al. (2016), who indicate an expanded and weak 330 Hadley circulation before 8 Ma.

331 The long-term Late Miocene El Niño-like state was interrupted by a brief interval (6.5 - 5.3

$332 \mathrm{Ma}$ ) during which the thermocline shoaled in the EEP, as shown by the $\delta^{18} \mathrm{O}$ gradient (Fig.

333 4B). The SST cooling and decrease of surface salinity recorded at Site U1338 (Rousselle et 334 al., 2013), supported by higher abundances of upwelling siliceous species during this interval 335 (Kamikuri et al., 2009), suggest the first establishment of the cold tongue and of upwelling in 336 the EEP. Increasing abundances of surface-dweller species at Site 806 (Nathan and Leckie, 337 2009) (Fig. 3 and 4), this interval further supports the idea of a weak and transient La Niña 338 like period. Drury et al. (2018) suggested a cooling of the thermocline waters related to the 339 global late Miocene cooling (Federov et al., 2006; Drury et al., 2017). Although the data do 340 not rule out this hypothesis, the $\mathrm{T}_{\mathrm{TEX}}$ cooling is supportive of a change in depth of GDGT 341 production or export in response to the onset of the EEP upwelling.

343 The oxygen-isotope and temperature data indicate a long-term gradual thermocline shoaling 344 and sea-surface cooling in the EEP (Fig. 4A, 4B) throughout this interval. In the WEP, the 345 thermocline shoaled between 5.3 and 4 Ma, returning to a deep position between 4 and 1.8 346 Ma and shoaling again after 1.8 Ma. This interval is characterized by the initiation of a 347 progressive asymmetry in the thermocline depth across the equatorial Pacific. 
After 5.3 Ma, SSTs at IODP Site U1338 were warm $\left(\sim 27{ }^{\circ} \mathrm{C}\right)$, in agreement with a deep thermocline until 4.5 Ma (Fig. 4A). This result is supported by a rapid increase of $\mathrm{T}_{\mathrm{TEX}}$ at U1338. Moreover, abundances of upwelling radiolarian species decreased again in the EEP (Kamikuri et al., 2009). In the WEP, the proto-warm pool period ended (Nathan and Leckie, 2009). This interval coincides with the Messinian salinity crisis (Hilgen et al., 2007), during which the isolation of the Mediterranean Sea would have triggered a reduction of the North Atlantic Deep Water formation (NADW) at $\sim 6$ Ma because of changing water density of the North Atlantic waters (Pérez-Asensio et al., 2012). According to model simulations, this process would result in a deepening of the thermocline in the equator and El Niño-like conditions (Rühlemann et al., 2004; Timmermann et al., 2005; Barreiro et al., 2008), thus providing a possible explanation to the results herein.

Numerous studies have focused on the magnitude of Pliocene equatorial Pacific warmth (4.5

$360-3.5 \mathrm{Ma}$ ) and the factors responsible for it (e.g., Raymo et al., 1996; Haywood and Valdes, 2004; Ravelo et al., 2004; Barreiro et al., 2008; Rickaby and Halloran, 2005; Brierley et al., 2009; Scroxton et al., 2011; Ford et al., 2015). It is accepted that during the mid-Piacenzian Warm Period, persistent El-Niño like conditions prevailed. This interval, also known as E1 364 Padre mean state (Ford et al., 2015), is characterized by a deep and warm thermocline and warm surface conditions across the equatorial Pacific.

366 The low-resolution record presented here suggests a brief interval centered around 4 Ma when 367 the thermocline deepened in the east and shoals in the west. SSTs in the EEP reach $30^{\circ} \mathrm{C}$ and 368 around $32^{\circ} \mathrm{C}$ in the WEP (Fig. 4A, 4C, Mg/Ca .ruber SSTs; Medina-Elizalde et al., 2008). 369 From 3.5 Ma, a pronounced zonal gradient of the thermocline depth and of the SSTs 370 developed across the Pacific. The SST cooling trend and shoaling of the thermocline 371 identified in the EEP coincides with the permanent establishment of the cold tongue 372 (Groeneveld et al., 2006; Dekens et al., 2007; Steph et al., 2010; Rousselle et al., 2013). This 
result is in agreement with Chaisson and Ravelo (2000) and Kamikuri et al., (2009), who

374 report higher abundances of subsurface-dweller foraminifera and radiolarian upwelling 375 species in the EEP at that time. Simultaneous with the changes in the EEP, the warm pool 376 became established and the thermocline deepened in the WEP, as suggested by warmer 377 surface waters and reduced $\Delta \mathrm{T}$ (Fig. 4C, Wara et al., 2005; Medina-Elizalde et al., 2008) and 378 planktonic foraminifera abundances (Cannariato and Ravelo, 1997; Chaisson and Ravelo, 379 2000; Li et al., 2006). This La Niña-like pattern is consistent with earlier studies (Rickaby and 380 Halloran 2005; Kamikuri et al., 2009; Steph et al., 2010; Ford et al., 2012 and Rousselle et al., 381 2013) in favor of an active equatorial upwelling and a strong Walker cell.

382 Between 1.8 and 1.3 Ma, data indicate that the thermocline tilt and the SST gradient across 383 the Pacific were reinforced (Fig. 4). This result is in agreement with the setting of the modern 384 cold tongue identified by Martinez-Garcia et al. (2011).

386 Prior research has attributed changes in the thermocline tilt to local tectonic events such as the 387 opening and closing of the Panama and Indonesian oceanic gateways (e.g., LaRiviere et al., 388 2012), and changes in sea-surface-temperature zonal gradients to global climate perturbations 389 or changes in regional wind patterns and strength (Hovan, 1995; Ford et al., 2012).

390 However, there is still a strong debate about the timing of the closure of these oceanic 391 gateways and their role in controlling the equatorial Pacific mean climate state. Montes et al., 392 (2012, 2015), Osborne et al. (2014), and Sepulchre et al. (2014) suggested that the Central 393 American Seaway was restricted by 10-11 Ma, which contradicts the commonly accepted late 394 Pliocene timing of its closure (Keigwin, 1982; Duque-Caro, 1990; Haug and Tiedemann, 395 1998; Haug et al., 2001). On the other hand, Molnar and Cronin (2015) showed a marked 396 restriction of the Indonesian Seaway from 5 Ma. This interpretation implies that the changes 
of the equatorial Pacific mean state during the Miocene would have been controlled mainly by global climate changes.

399 The brief La Niña-like interval between 6.5 and 5.3 Ma may be attributable to the combination of the restricted flow through the Central American Seaway (Keigwin, 1982; 401 Keller et al., 1989) and the $25 \mathrm{~m}$ sea-level drop at $~ 6.5 \mathrm{Ma}$ (Haq et al., 1987; Hardenbol et 402 al., 1998; Haq and Schutter, 2008) due to the expansion of ice sheets in Greenland (Larsen et al., 1994), Alaska (Bradshaw et al., 2012) and Antarctica (Billups, 2002; Williams et al. 2010) and the 2 Myr-long Northern Hemisphere glaciation (Larsen et al., 1994). This global cooling is thought to have contributed to the reinforcement of the equatorial upwelling and EUC. Data from sediments younger than $\sim 5 \mathrm{Ma}$ indicate an important change in the equatorial Pacific mean state with the dominance of La Niña-like intervals. The onset of this long-term state coincides with a drastic restriction of the Indonesian Seaway (Srinivasan and Sinha, 1998; Molnar and Cronin, 2015), and changes in the global climate. The Indonesian Seaway restriction is thought to have contributed to the cooling of the eastern tropical Pacific over the last $5 \mathrm{Myr}$ through the strengthening of the Walker circulation, leading to the increase in the

412 Pacific zonal temperature gradient (Fig. 3, 4).

413 The La Niña-like event between 1.8 and 1.3 Ma coincides with pronounced ice growth in 414 Antarctica (McKay et al., 2012) and the development of the northern-hemisphere ice sheets. 415 The gradual increase of the pole-to-equator temperature gradient is thought to have reinforced 416 the Walker cell, and affected the low-latitude zonal gradient (Molnar and Cane, 2002; McKay 417 et al., 2012). Furthermore, modelling experiments show a positive feedback of the Pliocene 418 low-latitude cooling on the global cooling (Fedorov et al., 2006). The shoaling of the 419 thermocline increased the climate sensitivity of this area by strengthening the temperature 420 gradient through the tropics and subsequently the Walker and Hadley cells (Brierley et al., 421 2009; Brierley and Fedorov, 2010). These processes led to the final setting of upwelling areas 
422 (Philander and Fedorov, 2003; Dekens et al., 2007; Brierley et al., 2009; Brierley and 423 Fedorov, 2010).

\section{CONCLUSION}

This study demonstrates the complexity of reconstructing the evolution of the equatorial Pacific mean climate state and oceanographic features and the need of a multi-proxy approach to get a comprehensive understanding of the mechanism at play over the past $10 \mathrm{Myr}$. Combined isotopic zonal gradients between the surface (Noelaerhabdaceae) and subsurface (G. menardii) waters from the east and west equatorial Pacific reveals important steps towards the establishment of what is known today as El Niño-Southern Oscillation. The record suggests a general shoaling of the thermocline along the equator since the Late Miocene. The data show the appearance of the cold tongue at $\sim 6.8 \mathrm{Ma}$ before its proper establishment around 4.4 to 3.6 Ma (Chaisson 1995; Cannariato and Ravelo, 1997; Chaisson and Ravelo, 2000; Molnar and Cane, 2002; Ravelo et al., 2004, 2006; Sato et al., 2008; Steph et al., 2010; Rousselle et al., 2013) and its modern configuration $\sim 1.8 \mathrm{Ma}$. This result is in agreement with

436 the findings of LaRivière et al. (2012) and Zhang et al., (2014), who suggested progressive 437 shoaling of the thermocline over the last 13 Myr.

The data indicate two critical transitions at about 5.3 Ma, when the thermocline globally started shoaling across the equatorial Pacific and around 3.8 Ma from an El-Niño-likedominated mean state during the Late Miocene to a La-Niña-like-dominated state during the Plio-Pleistocene. These transitions coincide with marked regional and global changes.

442 Locally, the restriction of the Indonesian Seaway and subsequent intensification of the Walker 443 circulation increased the Pacific zonal temperature gradient over the last 5 Myr. From a global 444 point of view, the growth of ice sheets in the northern hemisphere and in Antarctica most 445 likely affected the Walker cell and the low-latitude zonal gradient. 
448 We thank the European Consortium for Ocean Research Drilling (ECORD) for the ECORD

449 Grant. We are also grateful to Anchelique Mets and Jort Ossebaar for support with the TEX 86 450 measurements. We finally want to thank Fabrice Minoletti for providing us the separation 451 technique development necessary to then perform the isotopic measurements on 452 Noelaerhabdaceae calcite. We also thank the Ocean and International Ocean drilling Program 453 (ODP and IODP) for providing samples from Sites 806 and U1338. SS and AS were 454 supported by the Netherlands Earth System Science Center funded by the Dutch Ministry 455 Science and Education (OCW). MAS was supported by CNRS (Centre National de la 456 Recherche Scientifique) for salary. 
458 Backman, J., Baldauf, J.G., Ciummelli, M., and Raffi, I., 2016, Data report: a revised biomagnetostratigraphic age model for Site U1338, IODP Expedition 320/321: Proceedings of the Integrated Ocean Drilling Program, 320/321, http://doi.org/10.2204/iodp.proc.320321.219.2016.

462

Barreiro, M., Philander, G., Pacanowski, R., and Fedorov, A., 2005, Simulations of warm tropical conditions with application to middle Pliocene atmospheres: Climate Dynamics, v. 26, p. 349-365.

Barreiro, M., Fedorov, A., Pacanowski, R., and Philander, S.G., 2008, Abrupt climate changes: how freshening of the Northern Atlantic affects the thermohaline and winddriven oceanic circulations: Annual Review of Earth and Planetary Sciences, v. 36, p. $33-58$.

Beltran, C., Rousselle, G., Backman, J., Wade, B.S., and Sicre, M.A., 2014, Paleoenvironmental trigger for the development of bloom forming calcareous nannofossils: an example from the Late Miocene Eastern Equatorial Pacific: Palaeoceanography, v. 29 (3), p. 210-222.

Billups, K., 2002, Late Miocene through early Pliocene deep water circulation and climate change viewed from the sub-Antarctic South Atlantic: Palaeogeography, Palaeoclimatology, Palaeoecology, v. 185(3-4), p. 287-307.

Boccaletti, G., Pacanowski, R.C., Philander, S.G.H., and Fedorov, A.V., 2004, The thermal structure of the upper ocean: Journal of Physical Oceanography, v. 34, p. 888-902

Bradshaw, C.D., Lunt, D.J., Flecker, R., Salzmann, U., Pound, M.J., Haywood, A.M., and Eronen, J.T., 2012, The relative roles of $\mathrm{CO}_{2}$ and palaeogeography in determining late Miocene climate: Results from a terrestrial model-data comparison: Climate of the Past, v. 8, p. 1257-1285. 
Brassell, S.C., Eglinton, G., Marlowe, I.T., Pflaumann, U., and Sarnthein, M., 1986, Molecular stratigraphy: a new tool for climatic assessment: Nature, v. 320, p. 129-133.

Brierley, C.M., and Fedorov, A.V., 2010, Relative importance of meridional and zonal sea surface temperature gradients for the onset of the ice ages and Pliocene-Pleistocene climate evolution: Paleoceanography, v. 25, PA2214, doi: 10.1029/2009PA001809.

Brierley, C., Fedorov, A.V., Liu, Z., Herbert, T.D., Lawrence, K.T., and LaRivière, J.P., 488 2009, Greatly expanded tropical warm pool and weakened Hadley circulation in the 489 early Pliocene: Science, v. 323, p. 1714-1718.

Brzezinski, M.A., 1988, Vertical distribution of ammonium in stratified oligotrophic waters: Limnology and Oceanography, v. 33, p. 1176-1182.

Cane, M.A., 1998, A role for the tropical Pacific: Science, v. 282(5386), p. 59-61, doi: 10.1126/science.282.5386.59.

Cannariato, K.G., and Ravelo, A.C., 1997, Pliocene-Pleistocene evolution of eastern tropical 495 Pacific surface water circulation and thermocline depth: Paleoceanography, v. 12(6), p. $805-820$.

Chaisson W.P., 1995, Planctonic foraminiferal assemblages and paleoceanographic change in the trans-tropical Pacific Ocean: a comparison of West (leg 130) and East (leg 138), latest Miocene to Pleistocene: Proceedings of the Ocean Drilling Program, Scientific Results, v. 138, p. 555-581.

Chaisson, W.P., and Leckie, R.M., 1993, High-resolution Neogene planktonic foraminifer biostratigraphy of Site 806, Ontong Java Plateau (western equatorial Pacific), in Berger, W.H., Kroenke, L.W., Mayer, L.A., et al. eds., Proceedings of Ocean Drilling

Chaisson, W.P, and Ravelo, A.C., 2000, Pliocene development of the east-west hydrographic gradient in the equatorial Pacific: Paleoceanography, v. 15(5), p. 497-505. 
Conte, M.H., Sicre, M-A., Rühlemann, C., Weber, J.C., Schulte, S., Schulz-Bull, D., and Blanz, T., 2006, Global calibration of the alkenone unsaturation index $\left(\mathrm{U}^{\mathrm{K}}{ }_{37}\right)$ with surface water production temperature and a comparison of the core top integrated production temperatures recorded by $\mathrm{U}^{\mathrm{K}}{ }_{37}$ with overlying sea surface temperatures: Geochemistry Geophysics Geosystems, v. 7(2), p. 1-22.

Dekens, P.S., Ravelo, A.C., and McCarthy, M.D., 2007, Warm upwelling regions in the Pliocene warm period: Paleoceanography, v. 22, p. 1-12.

Dekens, P.S., Ravelo, A.C., McCarthy, M.D., and Edwards, C.A., 2008, A 5 million year comparison of $\mathrm{Mg} / \mathrm{Ca}$ and alkenone paleothermometers: Geochemistry, Geophysics, Geosystems, v. 9, doi:10.1029/2007GC001931.

Drury, A.J., Westerhold, T., Frederichs, T., Tian, J., Wilkens, R., Channell, J.E.T., Evans, H., John, C.M., Lyle, M., and Röhl, U., 2017, Late Miocene climate and time scale reconciliation: Accurate orbital calibration from a deep-sea perspective: Earth and Planetary Science Letters, v. 475, p. 254-266, doi:10.1016/j.eps1.2017.07.038.

Drury, A.J., Geoff, L., Gray, W.R., Lyle, M., Westerhold, T., Shevenell, A., and John, C., 2018, Deciphering the State of the Late Miocene to Early Pliocene Equatorial Pacific: Paleoceanography and Paleoclimatology, v. 33, doi:10.1002/2017PA003245.

Duque-Caro, H., 1990, Neogene stratigraphy, paleoceanography and paleobiogeography in northwest South America and the evolution of the Panama Seaway: Palaeogeography, Palaeoclimatology, Palaeoecology, v. 77, p. 203-234.

Farell, J.W., Raffi, I., Janecek, T.R., Murray, D.W., Levitan, M., Dadey, K.A., Emeis, K., Lyle, M., Flores, J.-A., and Hovan, S., 1995, Late Neogene sedimentation patterns in the eastern equatorial Pacific Ocean: Proceedings of the Ocean Drilling Program, Scientific Results, v. 138, p. 717-756. 
Fedorov, A.V., Dekens, P.S., McCarthy, M., Ravelo, A.C., DeMenocal, P.B., Barreiro, M., Pa canowki, R.C., and Philander, S.G., 2006, The Pliocene paradox (mechanisms for a permanent El Niño): Science, v. 312, p. 1485-1489.

Fedorov, A.V., Brierley, C.M., Lawrence, K.T., Liu, Z., Dekens, P.S., and Ravelo, A., 2013, Patterns and mechanisms of early Pliocene warmth: Nature, v. 496, p. 43-49, doi:10.1038/nature12003.

Ford, H.L., Ravelo, A.C., and Hovan, S., 2012, A deep Eastern Equatorial Pacific thermocline during the early Pliocene warm period: Earth and Planetary Science Letters, v. 355356, p. 152-161.

Ford, H.L., Ravelo, A.C., Dekens, P.S., LaRiviere, J.P., and Wara, M.W., 2015, The evolution of the equatorial thermocline and the early Pliocene El Padre mean state: Geophysical Research Letters, v. 42, p. 4878-4887, doi:10.1002/ 2015GL064215.

Groeneveld, J., Steph, S., Tiedemann, R., Garbe, D., Nürnberg, D., and Sturn, A., 2006, Pliocene mixed-layer oceanography for site 1241 , using combined $\mathrm{Mg} / \mathrm{Ca}$ and $\delta^{18} \mathrm{O}$ analyses of Globigerinoides sacculifer: Proceedings of the Ocean Drilling Program, Scientific Results, v. 202, p. 1-27.

Haq, B.U., and Schutter, S.R., 2008, A chronology of Paleozoic sea-level changes: Science, v. 322(5898), p. 64-68.

Haq, B.U., Hardenbol, J., and Vail, P.R., 1987, Chronology of fluctuating sea levels since the Triassic (250 million years ago to present): Science, v. 235, p. 1156-1167.

Hardenbol, J., Thierry, J., Farley, M.B., Jacquin, T., De Graciansky, P.C., and Vail, P., 1998, Mesozoic and Cenozoic sequence chronostratigraphic framework of European basins, in De Graciansky, P.-C., Hardenbol, J., Jacquin, T., Vail, P.R., and Farley, M.B., eds., Mesozoic and Cenozoic Sequence Stratigraphy of European Basins: SEPM, Special Publication 60, p. 3-13. 
Haug, G.H., and Tiedemann, R., 1998, Effect of the formation of the Isthmus of Panama on Atlantic Ocean thermohaline circulation: Nature, v. 393, p. 673-676.

Haug, G.H., Tiedemann, R., Zahn, R., and Ravelo, A.C., 2001, Role of Panama uplift on oceanic freshwater balance: Geology, v. 29, p. 207-210.

Haywood, A.M, and Valdes, P.J., 2004, Modelling middle Pliocene warmth: contribution of atmosphere, oceans and cryosphere: Earth and Planetary Science Letters, v. 218, p.

Herbert, T.D., Lawrence, K.T., Tzanova, A., Peterson, L.C., Caballero-Gill, R., and Kelly, C.S., 2016, Late Miocene global cooling and the rise of modern ecosystems: Nature Geoscience, v. 9, p. 843-847, doi:10.1038/NGEO2813.

Hertzberg J.E., Schmidt M.W., Bianchi, T.S., Smith, R.W., Shields, M.R., and Marcantonio, F., 2016, Comparison of eastern tropical Pacific TEX 86 and Globigerinoides ruber $\mathrm{Mg} / \mathrm{Ca}$ derived sea surface temperatures: Insights from the Holocene and Last Glacial Maximum: Earth and Planetary Science Letters, v. 434, p. 320-332.

Hilgen, F., Kuiper, K., Krijgsman, W., Snel, E., and Van Der Laan, E., 2007, Astronomical tuning as the basis for high resolution chronostratigraphy: the intricate history of the Messinian Salinity Crisis: Stratigraphy, v. 4(2-3), p. 231-238.

Hovan, S.A., 1995, Late Cenozoic atmospheric circulation intensity and climatic history recorded by eolian deposition in the eastern equatorial Pacific Ocean, Leg 138: Proceedings of the Ocean Drilling Program, Scientific Results, v. 138, p. 615625.

Huguet, C., Schimmelmann, A., Thunell, R., Lourens, L.J., Sinninghe Damsté, J., and Schouten, S., 2007, A study of the TEX 86 paleothermometer in the water column and sediments of the Santa Barbara Basin, California: Paleoceanography, v. 22, p. 9.

580 Huguet, C., Martrat, B., Grimalt, J.O., Sinninghe Damsté, J.S., and Schouten, S., 2011, 
Coherent millennial scale patterns in $\mathrm{U}^{\mathrm{K}}{ }_{37}$ and $\mathrm{TEX}^{\mathrm{H}}{ }_{86}$ temperature records during the penultimate interglacial-to-glacial cycle in the western Mediterranean: Paleoceanography, v. 26, p. 10.

584 Kamikuri, S., Motoyama, I., Nishi, H., and Iwai, M., 2009, Evolution of Eastern Warm Pool and upwelling processes since the middle Miocene based on analysis of radiolarian assemblages: response to Indonesian and Central American Seaways: Palaogeography, Palaeoclimatology, Palaeoecology, v. 280, p. 469-479.

Karner, M.B., Delong, E.F., and Karl, D.M., 2001, Archaeal dominance in the mesopelagic zone of the Pacific Ocean: Nature, v. 409, p. 507-510.

Keigwin, L.D., 1982, Isotope paleoceanography of the Caribbean and east Pacific: Role of Panama uplift in late Neogene time: Science, v. 217, p. 350-353.

Keller, G., Zenker, C.E., and Stone, S.M., 1989, Late Neogene history of the Pacific Caribbean gateway: Journal of South American Earth Sciences, v. 2(1), p. 73-108.

Kim, J.H., Schouten, S., Hopmans, E.C., Donner, B., and Sinninghe Damsté, J.S., 2008, Global sediment core-top calibration of the $\mathrm{TEX}_{86}$ paleothermometer in the ocean: Geochimica et Cosmochimica Acta, v. 72(4), p. 1154-1173.

Kim, J.H., Van Der Meer, J., Schouten, S., Helmke, P., Willmott, V., Sangiorgi, F., Koç, N., Hopmans, E.C., and Sinninghe Damsté, J.S., 2010, New indices and calibrations derived from the distribution of crenarchaeal isoprenoid tetraether lipids: implications for past sea surface temperature reconstructions: Geochimica et Cosmochimica Acta, v. 74, p. $4639-4654$.

Kim, J.H., Romero, O.E., Lohmann, G., Donner, B., Laepple, T., Haam, E., and Sinninghe 604 Damsté, J.S., 2012, Pronounced subsurface cooling of North Atlantic waters off Northwest Africa during Dansgaard - Oeschger interstadials: Earth and Planetary Science Letters, v. 339-340, p. 95-102. 
606 Könneke, M., Bernhard, A.E., De La Torre, J.R., Walker, C.B., Waterbury, J.B., and Stahl, D.A., 2005, Isolation of an autotrophic ammonia-oxidizing marine Archaeon: Nature, v. 437, p. 543-546.

Koutavas, A., Demenocal, G., Olive, C., and Lynch-Stieglitz, J., 2006, Mid-Holocene El Niño - Southern Oscillation (ENSO) attenuation revealed by individual foraminifera in eastern tropical Pacific sediments: Geology, v. 34, p. 993-996.

612 Kroenke, L.W., Berger, W.H., and Janecek, T.R., 1991, Site 806: Proceedings of the Ocean Drilling Program, Initial reports, v. 130, p. 291-367.

614 LaRivière, J.P., Ravelo, A.C., Crimmins, A., Dekens, P.S., Ford, H.L., Lyle, M., and Wara, M.W., 2012, Late Miocene decoupling of oceanic warmth and atmospheric carbon dioxide forcing: Nature, v. 486, p. 97-100.

Larsen, H.C., Saunders, A.D., Clift, P.D., Beget, J., Wei, W., and Spezzaferri, S., 1994, Seven million years of glaciation in Greenland: Science, v. 264, p. 952-955.

Lee, K.E., Kim, J.H., Wilke, I., Helmke, P., and Schouten, S., 2008, A study of the alkenone, $\mathrm{TEX}_{86}$, and planktonic foraminifera in the Benguela Upwelling System: Implications for past sea surface temperatures estimates: Geochemistry, Geophysics, Geosystems,

Leider, A., Hinrichs, K.U., Mollenhauer, G., and Versteegh, G.J.M., 2010, Core-top calibration of the lipid-based $\mathrm{U}^{\mathrm{K}}{ }_{37}$ and $\mathrm{TEX}_{86}$ temperature proxies on the southern Italian shelf (SW Adriatic Sea, Gulf of Taranto): Earth and Planetary Science Letters,

627 Li, Q., Li, B., Zhong, G., McGowran, B., Zhou, Z., Wang, J., and Wang, P., 2006, Late 628 Miocene development of the western Pacific warm pool: planktonic foraminifer and oxygen isotopic evidence: Palaeogeography, Palaeoclimatology, Palaeoecology, v. 237, p. $465-482$. 
Lopes Dos Santos, R.A., Prange, M., Castañeda, I.S., Schefuß, E., Mulitza, S., Schulz, M., Niedermeyer, E.M., Sinninghe Damsté, J.S., and Schouten, S., 2010, Glacial interglacial variability in Atlantic meridional overturning circulation and thermocline adjustments in the tropical North Atlantic: Earth and Planetary Science Letters, v. 300, p. $407-414$.

Martin, R.E., 1999, Taphonomy and temporal resolution of foraminiferal assemblages, in Sen Gupta, B.K., ed., Modern Foraminifera: Kluwer Academic Publishers, 371 p.

Martinez-Garcia, A., Rosell-Mele, A., Jaccard, S.L., Geibert, W., Sigman, D.M., and Haug, G.H., 2011, Southern Ocean dust-climate coupling over the past four million years: Nature, v. 476, p. 312-315, doi:10.1038/nature10310

McKay, R., Naish, T., Carter, L., Riesselman, C., Dunbar, R., Sjunneskog, C., Winter, D., Sangiorgi, F., Warren, C., Pagani, M., Schouten, S., Willmott, V., Levy, R., DeConto, R., and Powell, R.D., 2012, Antarctic and Southern Ocean influences on Late Pliocene global cooling: National Academy of Sciences Proceedings (United States of America), v. 109 (17), p. 6423-6428.

McPhaden, M.J., Zebiak, S.E., and Glantz, M.H., 2006, ENSO as an integrating concept in Earth science: Science, v. 314, p. 1740-1745.

Medina-Elizalde, M., and Lea, D.W., 2010, Late Pliocene equatorial Pacific: Paleoceanography, v. 25, PA2208, doi:10.1029/2009PA001780.

Medina-Elizalde, M., Lea, D.W., and Fantle, M.S., 2008, Implications of seawater $\mathrm{Mg} / \mathrm{Ca}$ variability for Plio-Pleistocene tropical climate reconstruction: Earth and Planetary Science Letters, v. 269, p. 584-594.

Minoletti, F., Hermoso, M., and Gressier, V., 2009, Separation of sedimentary micron-sized particles for palaeoceanography and calcareous nannoplankton biogeochemistry: Nature Protocols, v. 4(1), p. 14 - 24. 
Molnar, P., and Cane, M.A., 2002, El Niño's tropical climate and teleconnections as a blueprint for pre-Ice Age climate: Paleoceanography, v. 172, p. 1-13.

Molnar, P., and Cronin, T.W., 2015, Growth of the maritime continent and its possible contribution to recurring Ice Ages: Paleoceanography, v. 30, p. 196-225, doi:10.1002/2014PA002752.

Montes, C., Cardona, A., McFadden, R., Morón, S., Silva, J.C., Restrepo-Moreno, S., Ramirez, D., Hoyos, N., Wilson, J. Farris, D., Bayona, G., Jaramillo, C., Valencia, V., Bryan, J., and Flores, J.A., 2012, Evidence for middle Eocene and younger land emergence in Central Panama: Implications for Isthmus closure: Geological Society of America, Bulletin, v. 124, p. 780-799.

Montes, C., Cardona, A., Jaramillo, C., Pardo, A., Silva, J.C., Valencia, V., Ayala, C., PérezAngel, L.C., Rodriguez-Parra, L.A., Ramirez, V., and Niño, H., 2015, Middle Miocene closure of the Central American Seaway: Science, v. 348, p. 226-229, doi: 10.1126/science.aaa2815.

Mudelsee, M., and Raymo, M.E., 2005, Slow dynamics of the Northern Hemisphere glaciation: Paleoceanography, v. 20, PA4022, doi:10.1029/2005PA001153.

Murray, A.E., Blakis, A., Massana, R., Strawzewski, S., Passow, U., Alldredge, A., and Delong, E.F., 1999, A time series assessment of planktonic archaeal variability in the Santa Barbara Channel: Aquatic Microbial Ecology, v. 20, p. 129-145.

Nathan, S.A., and Leckie, R.M., 2009, Early history of the Western Pacific Warm Pool during the middle to late Miocene ( 13,2-5,8 Ma): Role of sea-level change and implications for equatorial circulation: Palaeogeography, Palaoclimatology, Palaeoecology, v. 274, p. 140-159.

Neelin, J.D., Battisti, D.S., Hirst, A.C., Jin, F.-F., Wakata, Y., Yamagata, T., and Zebiak, S.E., 1998, ENSO Theory: Journal of Geophysics Research, v. 103, p. 14,261-14,290. 
Osborne, A.H., Newkirk, D.R., Groeneveld, J., Martin, E.E., Tiedemann, R., and Frank, M., 2014, The seawater neodymium and lead isotope record of the final stages of Central American Seaway closure: Paleoceanography, v. 29(7), p. 715-729, doi:10.1002/2014PA002676.

Pagani, M., Liu, Z., LaRiviere, J., and Ravelo, A.C., 2010, High Earth-system climate sensitivity determined from Pliocene carbon dioxide concentrations: Nature Geoscience, v. 3, p. 27-30.

Pälike, H., Lyle, M., Nishi, H., Raffi, I., Gamage, K., Klaus, A., and the Expedition 320/321 Scientists, 2010, Site 1338: Proceedings of the International Ocean Drilling Program 320/321, Expedition Reports, v. 321, 141 p.

Pälike, H., Lyle, M.W., Nishi, H., Raffi, I., Ridgwell, A., Gamage, K., Klaus, A., Acton, G., Anderson, L., Backman, J., Baldauf, J., Beltran, C., Bohaty, S.M., Bown, P., Busch, W., Channell, J.E., Chun, C.O., Delaney, M., Dewangan, P., Dunkley Jones, T., Edgar, K.M., Evans, H., Fitch, P., Foster, G.L., Gussone, N., Hasegawa, H., Hathorne, E.C., Hayashi, H., Herrle, J.O., Holbourn, A., Hovan, S., Hyeong, K., Iijima, K., Ito, T., Kamikuri, S., Kimoto, K., Kuroda, J., Leon-Rodriguez, L., Malinverno, A., Moore, T.C.J.R., Murphy, B.H., Murphy, D.P., Nakamura, H., Ogane, K., Ohneiser, C., Richter, C., Robinson, R., Rohling, E.J., Romero, O., Sawada, K., Scher, H., Schneider, L., Sluijs, A., Takata, H., Tian, J., Tsujimoto, A., Wade, B.S., Westerhold, T., Wilkens, R., Williams, T., Wilson, P.A., Yamamoto, Y., Yamamoto, S., Yamazaki, T., and Zeebe, R.E., 2012, A Cenozoic record of the equatorial Pacific carbonate compensation depth: Nature, v. 488(7413), p. 609-614, doi:10.1038/nature11360.

Pearson, P.N., Van Dongen, B.E., Nicholas, C.J., Pancost, R.D., Schouten, S., Singano, J.M., and Wade, B.S., 2007, Stable warm tropical climate through the Eocene epoch: Geology, v. 35(3), p. 211-214. 
Pérez-Asensio, J.N., Schmiedl, G., Aguirre, J., and Civis, J., 2012, Impact of restriction of the Atlantic-Mediterranean gateway on the Mediterranean Outflow Water and eastern Atlantic circulation during the Messinian: Paleoceanography, v. 27 (3), PA3222, doi:10.1029/2012PA002309.

Philander, S., and Fedorov, A., 2003, Role of tropics in changing the response to Milankovich forcing some three million years ago: Paleoceanography, v. 18, doi:10.1029/2002PA000837.

Pisias, N.G., Mayer, L.A., Janecek, T.R., Palmer-Julson, A., and Van Andel, T.H., 1995, Proceedings of the Ocean Drilling Program, Scientific results, v. 138.

Prahl, F.G., Muehlhausen, L.A., and Zahnle, D.L., 1988, Further evaluation of long-chain alkenones as indicators of paleoceanographic conditions: Geochimica et Cosmochimica Acta, v. 52, p. 2303-2310.

Ravelo, A.C., and Fairbanks, R.G., 1992, Oxygen isotopic composition of multiple species of planktonic foraminifera: recorders of the modern photic zone temperature gradient: Paleoceanography, v. 7, p. 815-831.

Ravelo, A.C., and Shackleton, N.J., 1995, Evidence for surface-water circulation changes at Site 851 in the eastern tropical Pacific Ocean: Proceedings of the Ocean Drilling Program, Scientific Results, v. 138, p. 503-514.

Ravelo, A.C., Andreasen, D., Lyle, M., Olivarez, L., and Wara, M.W., 2004, Regional climate shifts caused by gradual global cooling in the Pliocene Epoch: Nature, v. 429, p. $263-$ 267.

Ravelo, A.C., Dekens, P.S., and McCarthy, M., 2006, Evidence for El Niño-like conditions during the Pliocene: Geological Society of America Today, v. 16(3), p. 4-11. 
Raymo, M.E., Grant, B., Horowitz, M., and Rau, G.H., 1996, Mid-Pliocene warmth: stronger greenhouse and stronger conveyor: Marine Micropaleontology, v. 27, p. 313326, doi:10.1016/0377-8398(95)00048-8.

Rickaby, R.E.M., and Halloran, P., 2005, Cool La Niña the warmth of the Pliocene: Science, v. 307 , p. $1948-1952$

Rommerskirchen, F., Condon, T., Mollenhauer, G., Dupont, L., and Schefuss, E., 2011, Miocene to Pliocene development of surface and subsurface temperatures in the Benguela Current system: Paleoceanography, v. 26, 15 p.

Roth, P.H., 1986, Mesozoic paleoceanography of the North Atlantic and Tethys Oceans, North Atlantic: Paleoceanography, v. 21, p. 299-320.

Rousselle, G., Beltran, C., Sicre, M.-A., Raffi, I., and De Rafélis, M., 2013, Sea-surface condition changes in the Equatorial pacific during the Mio-Pliocene as inferred from coccoliths geochemistry: Earth and Planetary Science Letters, v. 361, p. 412-421.

Rühlemann, C., Mulitza, S., Lohmann, G., Paul, A., Prange, M., and Wefer, G., 2004, Intermediate depth warming in the tropical Atlantic related to weakened thermohaline circulation: Combining paleoclimate data and modelling results for the last deglaciation: Paleoceanography, v. 19, 10 p.

Sato, K., Oda, M., Chiyonobu, S., Kimoto, K., Domitsu, H., and Ingle, J.C., 2008, Establishment of the western Pacific warm pool during the Pliocene: Evidence from planktic foraminifera, oxygen isotopes, and $\mathrm{Mg} / \mathrm{Ca}$ ratios: Palaeogeography, Palaeoclimatology, Palaeoecology, v. 265, p. 140-147.

Schneider, B., and Schmittner, A., 2006, Simulating the impact of the Panamanian seaway closure on ocean circulation, marine productivity and nutrient cycling: Earth and Planetary Science Letters, v. 246, p. 367-380. 
Schouten, S., Hopmans, E.C., Schefuss, E., and Sinninghe Damsté, J.S., 2002, Distributional variations in marine crenarchaeotal membrane lipids: a new tool for reconstructing ancient sea water temperatures?: Earth and Planetary Science Letters, v. 204, p. 265274.

Schouten, S., Huguet, C., Hopmans, E.C., Kienhuis, M.V.M., and Sinninghe Damsté, J.S., 2007, Improved analytical methodology and constraints on analysis of the TEX 86 paleothermometer by high performance liquid chromatography/atmospheric pressure chemical ionization-mass spectrometry: Analytical Chemistry, v. 79, p. 2940-2944.

Schouten, S., Hopmans, E.C., and Sinninghe Damsté, J.S., 2013, The organic geochemistry of glycerol dialkyl glycerol tetraether lipids: a review: Organic geochemistry, v. 54, p. $19-61$.

Scroxton, N., Bonham, S.G., Rickaby, R.E.M., Lawrence, S.H.F., Hermoso, M., and Haywood, A.M., 2011, Persistent El Niño-Southern Oscillation variation during the Pliocene Epoch: Paleoceanography, v. 26, PA2215, doi:10.1029/2010PA002097.

Seki, O., Foster, G.L., Schmidt D.N., Mackensen, A., Kawamura, K., and Pancost, R.D., 2010, Alkenone and boron-based Pliocene $\mathrm{pCO}_{2}$ records: Earth and Planetary Science Letters, v. 292, p. 201-211, doi:10.1016/j.eps1.2010.01.037.

Seki, O., Schmidt, D.N., Schouten, S., Hopmans, E.C, Sinninghe Damsté, J.S., and Pancost, R.D., 2012, Paleoceanographic changes in the Eastern Equatorial Pacific over the last 10 Myr: Paleoceanography, v. 27, PA3224, doi:10.1029/2011PA002158.

Sepulchre, P., Arsouze, T., Donnadieu, Y., Dutay, J.C., Jaramillo, C., Le Bras, J., Martin, E., Montes, C., and Waite, A., 2014, Consequences of shoaling of the Central American Seaway determined from modeling Nd isotopes: Paleoceanography, v. 29, p. 176-189, doi:10.1002/2013PA002501. 
Sinninghe Damsté, J.S., Hopmans, E.C., Schouten, S., Van Duin, A.C.T., and Geenevasen, J.A.J., 2002, Crenarchaeol: the characteristic core glycerol dibiphytanyl glycerol tetraether membrane lipid of cosmopolitan pelagic crenarchaeota: Journal of Lipid Research, v. 43, p. 1641-1651.

Spero, H.J., Mielke, K.M., Kalve, E.M., Lea, D.W., and Pak, D.K., 2003, Multispecies approach to reconstructing eastern equatorial Pacific thermocline hydrography during the past 360 kyr: Paleoceanography, v. 18(1), p. 1-16.

Srinivasan, M.S., and Sinha, D.K., 1998, Early Pliocene closing of the Indonesian Seaway: evidence from north-east Indian Ocean and Tropical Pacific deep sea cores: Journal of Asian Earth Sciences, v. 16(1), p. 29-44.

Steph, S., Tiedemann, R., Prange, M., Groeneveld, J., Schulz, M., Timmermann, A., Nürnberg, D., Rühlemann, C., Saukel, C., and Haug, G.H., 2010, Early Pliocene increase in thermohaline overturning: A precondition for the development of the modern equatorial Pacific cold tongue: Paleoceanography, v. 252, 17 p.

Takayama, T., 1993, Notes on Neogene calcareous nannofossil biostratigraphy of the Ontong Java Plateau and size variations of Reticulofenestra coccoliths, in Berger, W.H., Kroenke, L.W., Mayer, L.A., et al. eds., Proceedings of the Ocean Drilling Program: Scientific Results, v. 130, p. 179-229.

Ternois, Y., Sicre, M.-A., and Paterne, M., 2000, Climatic changes along the northwestern African continental margin over the last 30 kyrs: Geophysical Research Letters, v. 27(1), p. 133-136.

Tian, B., Zhang, G.J., and Ramanathan, V., 2001, Heat balance in the Pacific warm pool atmosphere during TOGA COARE and CEPEX: Journal of Climate, v. 14(8), p. 1881-1893. 
801

802

803

804

805

806

807

808

809

810

811

812

813

814

815

816

817

818

819

820

821

822

823

824

Tierney, J.E., and Tingley, M.P., 2015, A TEX 86 surface sediment database and extended Bayesian calibration: Scientific Data, 2150029, doi: 10.1038/sdata.2015.29.

Tierney, J.E., and Tingley, M.P., 2018, BAYSPLINE: A new calibration for the alkenone paleothermometer: Paleoceanography and Paleoclimatology, v. 33, p. 281-301, doi:10.1002/2017PA003201.

Timmermann, A., An, S.I., Krebs, U., and Goosse, H., 2005, ENSO Suppression due to weakening of the North Atlantic thermohaline circulation: Journal of Climate, v. 18, p. $3122-3139$.

Wakeham, S.G., Peterson, M.L., Hedges, J.I., and Lee, C., 2002, Lipid biomarker fluxes in the Arabian Sea, with a comparison to the equatorial Pacific Ocean: Deep-Sea Research II, v. 49, p. 2265-2301.

Wakeham, S.G., Hopmans, E.C., Schouten, S., and Sinninghe Damsté J.S., 2004, Archaeal lipids and anaerobic oxidation of methane in euxinic water columns: A comparative study of the Black Sea and Cariaco Basin: Chemical Geology, v. 205, p. 427-442.

Wara, M.W., Ravelo, A.C., and Delaney, M.L., 2005, Permanent El Niño-Like Conditions During the Pliocene Warm Period: Science, v. 309, p. 758-761.

Williams, T., Van De Flierdt, T., Hemming, S.R., Chung, E., Roy, M., and Goldstein, S.L., 2010, Evidence for iceberg armadas from East Antarctica in the Southern Ocean during the late Miocene and early Pliocene: Earth and Planetary Science Letters, v. 290, p. 351-361.

Woodruff, F., and Savin, S.M., 1989, Miocene deep water oceanography: Paleoceanography, v. 4(1), p. $87-140$.

Wuchter, C., Schouten, S., Wakeham, S.G., and Sinninghe Damsté, J.S., 2005, Temporal and spatial variation in tetraether membrane lipids of marine Crenarchaeota in particulate 

PA3013, doi:10.1029/2004PA001110.

827 Yin, J.H., and Battisti, D. S., 2001, The importance of tropical sea surface temperature patterns in simulations of Last Glacial Maximum climate: Journal of Climate, v. 14, p. $565-581$.

830 Zhang, Y.G., Pagani, M., and Liu, Z., 2014, A 12-million-year temperature history of the 831 tropical Pacific Ocean: Science, v. 344, p. 84-86.

832 
834 Figure 1. A) Modern equatorial Pacific sea-surface temperatures (SSTs) from Ocean Data

835 View. The white dots show the location of the study sites, ODP 806 and IODP U1338. The 836 gray dots indicate the sites of previously published oxygen-isotope records (ODP 847 and 837 1241). WPWP, Western Pacific Warm Pool; EPWP, Eastern Pacific Warm Pool; NEC, North 838 Equatorial Current; SEC, South Equatorial Current; EUC, Equatorial Under Current; NECC, 839 North Equatorial Counter Current, PC, Peru Current (modified after Pisias et al., 1995). B)

840 Cross sections of temperature (colors) and currents (vectors) averaged over $2.5^{\circ} \mathrm{S}-2.5^{\circ} \mathrm{N}$ 841 (modified after US CLIVAR).

842

843 Figure 2. Comparison of El Niño-like (in red) and La Niña-like (in blue) time periods 844 inferred from previous studies using different proxies from the EEP and WEP over the past 12 845 Myrs.

846

847 Figure 3. A) $\delta^{18} \mathrm{O}$ records in the EEP. $\delta^{18} \mathrm{O}_{\text {Noelaerhabdaceae }}$ at IODP Site U1338 from Rousselle 848 et al. (2013), $\delta^{18} \mathrm{O}_{\text {G. sacculifer }}$ and $\delta^{18} \mathrm{O}_{\text {G. tumida }}$ at site 847 from Wara et al. (2005), $\delta^{18} \mathrm{O}_{\text {G. menardii }}$ 849 at Site U1338. B) $\delta^{18} \mathrm{O}$ records in the WEP. $\delta^{18} \mathrm{O}_{\text {Noelaerhabdaceae }}$ and $\delta^{18} \mathrm{O}_{\text {G. menardii }}$ at ODP Site 850806.

852 Figure 4. A) Temperature records at IODP Site U1338 (EEP): $\mathrm{U}^{\mathrm{K}}{ }^{\prime}{ }_{37}$-derived SST and TEX ${ }_{86}{ }^{-}$ 853 derived temperatures. The shaded areas represent the error bars of the temperature estimates 854 (light blue: $\mathrm{TEX}_{86}$-derived temperatures and dark blue: $\mathrm{U}^{\mathrm{K}}{ }^{37}$-derived SST). The arrows (black 855 and blue) highlight the temperature trends. B) Isotopic gradient $\left(\Delta \delta^{18} \mathrm{O}\right)$ between surface and 856 thermocline waters at IODP site U1338 (EEP) and ODP Site 806 (WEP). The evolution of the 857 thermocline depth in the EEP and the WEP over the last $10 \mathrm{Ma}$ according to the $\Delta \delta^{18} \mathrm{O}$ is also 
858 shown. C) Temperature records at ODP Site 806: $\mathrm{U}^{\mathrm{K}}{ }^{37}$-derived SST (Pagani et al., 2010) in 859 green, $\mathrm{TEX}_{86}$-derived temperatures (Zhang et al., 2014) in red, $\mathrm{Mg} / \mathrm{Ca}_{\text {G.ruber }}$-derived SST 860 (Medina-Elizalde et al., 2008) in brown and $\mathrm{Mg} / \mathrm{Ca}_{G . t u m i d a}$-derived temperature (Ford et al., 861 2015) in orange. 